\title{
Is There A Regional Bias In The Distribution Of Federal Aid To States
}

\author{
Richard B. McKenzie*
}

The question in the title of this paper is of paramount concern to policy makers, especially policy makers in the North. There people fear that the presumed warped flow of federal dollars away from northern industrial tier states and toward southern and western states partially explains the relatively sluggish growth of northern states. Wide variation in total and per capita flow of federal aid is evident in Table 1. Measures of the "balance of payments" with the federal treasury do in fact indicate a regional bias. ${ }^{1}$ Most (but not all) deficits in the federal balance of payments are found in northern states, whereas most surpluses are found in southern and western states.

The Northeast-Midwest Institute, a research arm of a coalition of 213 northern members of Congress (prior to the 1982 reapportionment), estimates that in the period from 1975 to 1979, the Northeast and Midwest area $^{2}$ sent to Washington $\$ 165$ billion more in federal taxes than it received back in federal outlays. In 1979, the Northeast-Midwest region received $\$ .84$ from the federal government for every federal tax dollar extracted. ${ }^{3}$ Additionally, the Institute concludes that "[c] urrent inequities in many federal aid programs have placed heavier burdens on the states in the region [than other federal expenditure categories]."

The purpose of this paper is straightforward: to answer empirically the question in the title-to assess, by way of ordinary least squares regression analysis, the extent to which a regional bias exists in the distribution of federal aid. The statistical analysis is broken into two main components, (1) aggregate federal aid flows across states and (2) federal aid flows disaggregated among six funding categories. In the study of aggregate aid flows, the analysis covers two years, 1970 and 1979 (the latest year for which all relevant data is available), and the changes that occurred between those years. Because of inconsistencies in the ways aid was classified in different years, our analysis of disaggregated aid flows is restricted to 1979. Again, the focus of this article is on the flow of federal funds from Washington to states independent of the flow of taxes from states to Washington. The net flow of dollars between states and Washington will be the subject of another paper.

\footnotetext{
*The author is a senior fellow at the Heritage Foundation on leave from the economics faculty at Clemson University. He is indebted to Ben Hawkins, Bruce Yandle, and referees for helpful substantive comments in the development of this paper, to Lisa Kiel for editorial assistance, and to Curtis Middleton for the computer work.
} 
TABLE 1

Federal Grants to States, Total and Per Capita, 1970 and 1979

\begin{tabular}{|c|c|c|c|c|}
\hline \multirow[b]{2}{*}{ State. } & \multicolumn{2}{|c|}{1970} & \multicolumn{2}{|c|}{1979} \\
\hline & $\begin{array}{c}\text { Total } \\
\text { (Millions } \\
\text { of dollars) }\end{array}$ & Per Capita & $\begin{array}{c}\text { Total } \\
\text { (Millions } \\
\text { of dollars) }\end{array}$ & Per Capita \\
\hline ALABAMA & 518 & 147 & 1368 & 363 \\
\hline ALASKA & 102 & 361 & 389 & 958 \\
\hline ARIZONA & 230 & 136 & 809 & 330 \\
\hline ARKANSAS & 273 & 137 & 847 & 389 \\
\hline CALIFORNIA & 2969 & 153 & 8251 & 364 \\
\hline COLORADO & 277 & 132 & 943 & 340 \\
\hline CONNECTICUT & 295 & 98 & 1075 & 345 \\
\hline DELAWARE & 50 & 93 & 233 & 400 \\
\hline FLORIDA & 507 & 80 & 2398 & 271 \\
\hline GEORGIA & 552 & 119 & 2181 & 426 \\
\hline HAWAII & 118 & 149 & 408 & 446 \\
\hline IDAHO & 90 & 125 & 337 & 372 \\
\hline ILLINOIS & 948 & 86 & 3783 & 337 \\
\hline INDIANA & 339 & 66 & 1392 & 258 \\
\hline IOWA & 243 & 87 & 878 & 303 \\
\hline KANSAS & 230 & 99 & 723 & 305 \\
\hline KENTUCKY & 453 & 140 & 1350 & 383 \\
\hline LOUISIANA & 523 & 140 & 1513 & 377 \\
\hline MAINE & 112 & 114 & 508 & 463 \\
\hline MARYLAND & 394 & 105 & 1578 & 380 \\
\hline MASSACHUSETTS & 714 & 131 & 2726 & 473 \\
\hline MICHIGAN & 765 & 87 & 3569 & 388 \\
\hline MINNESOTA & 405 & 109 & 1515 & 373 \\
\hline MISSISSIPPI & 409 & 173 & 1046 & 431 \\
\hline MISSOURI & 500 & 108 & 1514 & 311 \\
\hline MONTANA & 127 & 183 & 434 & 552 \\
\hline NEBRASKA & 128 & 87 & 475 & 302 \\
\hline NEVADA & 76 & 165 & 277 & 395 \\
\hline NEW HAMPSHIRE & 72 & 100 & 293 & 330 \\
\hline NEW JERSEY & 618 & 87 & 2716 & 370 \\
\hline NEW MEXICO & 202 & 203 & 617 & 497 \\
\hline NEW YORK & 2364 & 129 & 8872 & 503 \\
\hline NORTH CAROLINA & 505 & 97 & 1789 & 319 \\
\hline NORTH DAKOTA & 86 & 140 & 295 & 449 \\
\hline OHIO & 887 & 83 & 3071 & 286 \\
\hline OKLAHOMA & 401 & 156 & 949 & 328 \\
\hline OREGON & 234 & 115 & 1071 & 424 \\
\hline PENNSYLVANIA & 1342 & 114 & 4099 & 349 \\
\hline RHODE ISLAND & 132 & 146 & 412 & 443 \\
\hline SOUTH CAROLINA & 276 & 103 & 987 & 337 \\
\hline SOUTH DAKOTA & 101 & 154 & 316 & 459 \\
\hline TENNESSEE & 476 & 120 & 1507 & 344 \\
\hline
\end{tabular}


TABLE 1

Federal Grants to States, Total and Per Capita, 1970 and 1979

\begin{tabular}{lccccc}
\hline & \multicolumn{2}{c}{1970} & & \multicolumn{2}{c}{1979} \\
\cline { 2 - 3 } \cline { 5 - 6 } State & $\begin{array}{c}\text { Total } \\
\text { (Millions } \\
\text { of dollars) }\end{array}$ & Per Capita & & $\begin{array}{c}\text { Total } \\
\text { (Millions } \\
\text { of dollars) }\end{array}$ & Per Capita \\
\hline TEXAS & 1149 & 103 & & 3592 & 268 \\
UTAH & 169 & 162 & & 456 & 334 \\
VERMONT & 76 & 174 & & 242 & 491 \\
VIRGINIA & 465 & 100 & & 1701 & 327 \\
WASHINGTON & 386 & 114 & & 1417 & 361 \\
WEST VIRGINIA & 303 & 167 & & 772 & 411 \\
WISCONSIN & 367 & 87 & & 1725 & 365 \\
WYOMING & 64 & 201 & & 243 & 540 \\
UNITED STATES & 24,194 & 110 & & 80,800 & 367 \\
& & & & \\
\hline
\end{tabular}

Source: For details on programs covered, see U.S. Department of the Treasury, Federal Aid to States, 1980. Data includes (a) direct cash grants, (b) outlays for grants-in-kind, (c) payments to non-profit institutions when approved by government, (d) payments to Indian governments, (e) payments to regional commissions, (f) payments for research and development, and $(\mathrm{g})$ shared revenue. It does not include (a) federal administrative expenses, (b) grants directly to profit-making entities and nonprofit concerns not covered above, (c) payments for basic research, and (d) payments for goods and services purchased by the fed eral government. Programs under 92 headings were covered in 1979. Total federal aid represented 12.4 and 16.6 percent of total federal expenditures in 1970 and 1979 , respectively.

The answer to the question in the title may shed light on another question currently perplexing public policy officials: Will there be a regional bias to any across-the-board cuts in the federal aid system, such as the cuts proposed by the Reagan Administration. Admittedly, any answer given to the latter question must be tentative, since the regional biases depend on which, and by how much, federal programs are cut, and since the particulars of the cuts in federal aid and the "swaps" in aid responsibilities between the states and federal government have not, at this writing (early 1982), been resolved by Congress.

\section{AGGREGATE FEDERAL AID FLOWS TO STATES}

\section{The Unadjusted Flows}

On the basis of primitive analysis (not reported in detail here), regressing total state aid against only dummy variables for the eight Census Bureau divisions other than the South Atlantic, ${ }^{5}$ a regional bias clearly does exist. Relative to the South Atlantic, however, the bias for 1970 and 1979 is solely in favor of the Mid Atlantic. By being located in the Mid Atlantic in 1970, a state received on average a little more than a $\$ 1$ billion in additional federal aid; the advantage to states in the division in 1979 was 3.5 times that amount, reflecting the more than three-fold expansion in total federal aid over the interim. 


\section{TABLE 2.}

Federal Aid to States Per Capita, 1970 and 1979

\begin{tabular}{|c|c|c|c|c|c|c|}
\hline \multirow[b]{2}{*}{$\begin{array}{l}\text { Census Bureau } \\
\text { Divisions }\end{array}$} & \multicolumn{3}{|c|}{1970} & \multicolumn{3}{|c|}{1979} \\
\hline & Estimate & T-Statistic & $\begin{array}{c}\text { Significance } \\
\text { Level }\end{array}$ & Estimate & T-Statistic & $\begin{array}{c}\text { Significance } \\
\text { Level }\end{array}$ \\
\hline Intercept & 0.0972 & 8.72 & 0.0001 & 0.3589 & 9.90 & 0.0001 \\
\hline New England & 0.0262 & 1.54 & 0.1313 & 0.0652 & 1.18 & 0.2456 \\
\hline Mid Atlantic & 0.0124 & 0.58 & 0.5640 & 0.0485 & 0.70 & 0.4885 \\
\hline East North Central & -0.0167 & -0.93 & 0.3569 & -0.0321 & -0.55 & 0.5851 \\
\hline West North Central & 0.0137 & 0.84 & 0.4030 & -0.0016 & -0.03 & 0.9756 \\
\hline Mountain & 0.0604 & 3.83 & 0.0004 & 0.0610 & 1.19 & 0.2407 \\
\hline Pacific & 0.0875 & 4.87 & 0.0001 & 0.1513 & 2.59 & 0.0133 \\
\hline East South Central & 0.0515 & 2.67 & 0.0109 & 0.0211 & 0.34 & 0.7383 \\
\hline West South Central & 0.0384 & 1.99 & 0.0532 & -0.0185 & -0.30 & 0.7693 \\
\hline Mean & 0.1270 & & & 0.3914 & & \\
\hline $\mathrm{R}^{2}$ & 0.5358 & & & 0.2353 & & \\
\hline F value & 5.92 & & 0.0001 & 1.58 & & 0.1616 \\
\hline
\end{tabular}


An obvious explanation for the regional bias in total aid is the concentration of the country's population in the Mid Atlantic. Hence, federal aid per capita was, in independent runs for 1970 and 1979, regressed against the eight dummy variables for the regions. The results of those runs are reported in Table 2. Relative to the South Atlantic, there was no apparent bias in 1970 and 1979 for four of the eight divisions, New England, Mid Atlantic, East North Central, and West North Central. There was in $1970 \mathrm{a}$ statistical bias in favor of the other four (at a confidence level of .10 or below). However, by 1979 only the positive bias in favor of the Pacific remained highly significant. That finding must remain suspect because of the relatively low $\mathrm{F}$ value for the equation.

\section{The Adjusted Flows}

The federal aid system has been designed intentionally to remedy problems of "fiscal disparity" among states - that is, to redistribute government purchasing power from financially strapped states to financially strong states. ${ }^{6}$ In the federal grant formulas, state income per capita often is used as a proxy for states' fiscal capacity, whereas state and local taxes per capita have been employed to reflect "need" for federal assistance. From earlier empirical work on the determinants of the distribution of federal aid, ${ }^{7}$ we know that state and local taxes per capita, state income per capita, and the proportion of the state's population residing in urban areas are reasonably powerful determinants of the flow of federal funds across states. Therefore, our analysis of regional bias of federal aid to states per capita was extended to include those three variables along with the eight regional dummy variables.

The results of investigations of federal aid flows for 1970 and 1979, adjusted for tax, income, and urbanization differences, are reported in Table 3. As was found in earlier work, the investigation revealed state and local taxes and state income in 1970 were insignificant determinants of the flow of federal funds across states. On the other hand, the degree of urbanization was negative and highly significant. Vis a vis the South Atlantic, there was also a highly significant bias (at the .10 level or lower) in favor of four divisions, Mountain, Pacific, East South Central, and West South Central. Looked at differently, after adjusting for income, state and local taxes, urbanization, and population, the other five regions did not, within the limitations of this study, get their "fair share." That is, they received less than one would have expected based upon the states' fiscal capacity and need and degree of urbanization. It should be stressed that such favorable bias in 1970 for several south western and western divisions translates into a regional bias against one prominent Sunbelt division, the South Atlantic.

\section{The bias was not totally against the Frostbelt.}

Further analysis indicates that the regional bias that existed in 1970 had by the end of the decade been eliminated. As opposed to regional biases driving the distribution, federal aid was being dispersed to a much greater 
TABLE 3.

Federal Aid to States Per Capita, Adjusted, 1970 and 1979

\begin{tabular}{|c|c|c|c|c|c|c|}
\hline \multirow[b]{2}{*}{$\begin{array}{c}\text { Census Bureau } \\
\text { Divisions }\end{array}$} & \multicolumn{3}{|c|}{1970} & \multicolumn{3}{|c|}{1979} \\
\hline & Estimate & T-Statistic & $\begin{array}{c}\text { Significance } \\
\text { Level }\end{array}$ & Estimate & T-Statistic & $\begin{array}{c}\text { Significance } \\
\text { Level }\end{array}$ \\
\hline Intercept & 0.1991 & 5.60 & 0.0001 & 0.4845 & 6.53 & 0.0001 \\
\hline New England & .0126 & 0.84 & 0.4034 & 0.0320 & 1.28 & 0.2088 \\
\hline Mid Atlantic & 0.0172 & 0.89 & 0.3791 & 0.0096 & 0.31 & 0.7610 \\
\hline East North Central & -0.0148 & -0.95 & 0.3459 & -0.0124 & -0.49 & 0.6293 \\
\hline West North Central & -0.0065 & -0.45 & 0.6544 & -0.0312 & -1.32 & 0.1949 \\
\hline Mountain & 0.0460 & 3.29 & 0.0022 & 0.0054 & 0.24 & 0.8106 \\
\hline Pacific & 0.0681 & 3.76 & 0.0006 & 0.0255 & 0.88 & 0.3868 \\
\hline East South Central & 0.0399 & 2.43 & 0.0200 & 0.0141 & 0.50 & 0.6197 \\
\hline West South Central & 0.0351 & 2.18 & 0.0359 & 0.0077 & 0.29 & 0.7743 \\
\hline $\begin{array}{l}\text { State and Local } \\
\text { Taxes Per Capita }\end{array}$ & 0.0636 & 0.76 & 0.4515 & 0.4000 & 11.19 & 0.0001 \\
\hline $\begin{array}{l}\text { State Income Per } \\
\text { Capita }\end{array}$ & 0.0005 & 0.06 & 0.9550 & -0.0457 & -3.62 & 0.0009 \\
\hline $\begin{array}{l}\text { Percentage of } \\
\text { Population in } \\
\text { Urban Area }\end{array}$ & 0.0007 & -4.54 & 0.0001 & -0.0013 & -2.99 & 0.0050 \\
\hline Mean & 0.1270 & & & 0.3862 & & \\
\hline $\mathbf{R}^{2}$ & 0.7032 & & & 0.8724 & & \\
\hline $\mathrm{F}$ value & 8.18 & & 0.0001 & 22.38 & & 0.0001 \\
\hline
\end{tabular}


extent on the bases of state and local taxes, positive and significant at the .0001 confidence level; state income, negative and significant at the .001 level; and urbanization, negative and significant at the .008 level. (Without the urbanization variable included, the general conclusions reported in Table 3 remain unchanged.)

\section{The Change in the Aggregate Flows between 1970-1979}

The results of our investigation of the determinants of the growth in real federal aid going to states are summarized in Table 4 . The change in real per capita federal aid between 1970 and 1979 was regressed against state and local taxes per capita, state income per capita, degree of urbanization, and the eight regional variables. The table reveals a very strong positive relationship between the growth in state and local taxes per capita and federal aid per capita. It also shows, relative to the South Atlantic, a strong regional bias against the Mountain, East South Central, and West South Central. One plausible explanation for this latter finding is that the federal aid system was designed to aid disproportionately the relatively low income states; and since states in those three regions at the beginning of the decades generally ranked low in per capita income and experienced relatively faster growth in state income through the decade, they did not

TABLE 4.

Change in Real Federal Aid Per Capita, Adjusted, between 1970 and 1979

\begin{tabular}{|c|c|c|c|}
\hline $\begin{array}{l}\text { Censes Bureau } \\
\text { Divisions }\end{array}$ & Estimate & T-Statistic & $\begin{array}{c}\text { Significance } \\
\text { Level }\end{array}$ \\
\hline Intercept & 0.0765 & 6.62 & 0.0001 \\
\hline New England & 0.0167 & 1.25 & 0.2197 \\
\hline Mid Atlantic & 0.0164 & 1.01 & 0.3199 \\
\hline East North Central & 0.0097 & 0.74 & 0.4661 \\
\hline West North Central & -0.0028 & -0.23 & 0.8174 \\
\hline Mountain & -0.283 & -2.38 & 0.0230 \\
\hline Pacific & -0.0121 & -0.81 & 0.4240 \\
\hline East South Central & -0.0299 & -2.07 & 0.0461 \\
\hline West South Central & -0.0415 & -2.85 & 0.0072 \\
\hline $\begin{array}{l}\text { Change in Real State } \\
\text { and Local Taxes Per } \\
\text { Capita }\end{array}$ & 0.1875 & 4.27 & 0.0001 \\
\hline $\begin{array}{l}\text { Change in Real State } \\
\text { Income Per Capita }\end{array}$ & 0.0022 & -0.19 & 0.8501 \\
\hline $\begin{array}{l}\text { Change in Percentage of } \\
\text { Population in Urban } \\
\text { Areas }\end{array}$ & -0.0005 & -1.17 & 0.2505 \\
\hline Mean & 0.0799 & & \\
\hline $\mathrm{R}^{2}$ & 0.7270 & & \\
\hline $\mathrm{F}$ value & 8.72 & & 0.0001 \\
\hline
\end{tabular}


TABLE 5

Federal Aid Per Capita by Categories, Unadjusted, 1979

\begin{tabular}{|c|c|c|c|c|c|c|c|c|c|}
\hline \multirow[b]{2}{*}{$\begin{array}{l}\text { Census Bureau } \\
\text { Divisions }\end{array}$} & \multicolumn{3}{|c|}{ Health and Welfare } & \multicolumn{3}{|c|}{ Education } & \multicolumn{3}{|c|}{$\begin{array}{l}\text { Housing and Community } \\
\text { Development }\end{array}$} \\
\hline & Estimate & $\begin{array}{c}\mathrm{T}- \\
\text { Statistic }\end{array}$ & $\begin{array}{c}\text { Signif- } \\
\text { icance } \\
\text { Level }\end{array}$ & Estimate & $\begin{array}{c}\mathrm{T}- \\
\text { Statistic }\end{array}$ & $\begin{array}{c}\text { Signif- } \\
\text { icance } \\
\text { Level }\end{array}$ & Estimate & $\begin{array}{c}\mathrm{T}- \\
\text { Statistic }\end{array}$ & $\begin{array}{l}\text { Signif- } \\
\text { icance } \\
\text { Level }\end{array}$ \\
\hline Intercept & 0.1148 & 8.52 & 0.0001 & 0.0175 & 7.34 & 0.0001 & 0.0241 & 10.98 & 0.0001 \\
\hline New England & 0.0822 & 3.99 & 0.0003 & -0.0028 & -0.78 & 0.4386 & 0.0065 & 1.94 & 0.0593 \\
\hline Mid Atlantic & 0.0883 & 3.42 & 0.0014 & -0.0054 & -1.19 & 0.2399 & 0.0107 & 2.55 & 0.0144 \\
\hline East North Central & 0.0387 & 1.78 & 0.0821 & -0.0047 & -1.24 & 0.2225 & -0.0014 & -0.40 & 0.6891 \\
\hline West North Central & 0.0013 & 0.07 & 0.9465 & -0.0013 & -0.39 & 0.6984 & 0.0003 & 0.10 & 0.9242 \\
\hline Mountain & -0.0255 & -1.34 & 0.1878 & -0.0004 & -0.14 & 0.8920 & -0.0060 & -1.95 & 0.0581 \\
\hline Pacific & 0.0301 & 1.39 & 0.1735 & -0.0001 & -0.04 & 0.9664 & -0.0004 & -0.12 & 0.9060 \\
\hline East South Central & 0.0309 & 1.33 & 0.1922 & 0.0006 & 0.16 & 0.8751 & 0.0022 & 0.58 & 0.5623 \\
\hline West South Central & 0.0377 & 1.62 & 0.1135 & -0.0015 & -0.37 & 0.7113 & 0.0003 & 0.09 & 0.9308 \\
\hline Mean & 0.1384 & & & 0.0160 & & & 0.0246 & & \\
\hline $\mathrm{R}^{2}$ & 0.5131 & & & 0.0813 & & & 0.3657 & & \\
\hline $\mathrm{F}$ value & 5.40 & & 0.0001 & 0.45 & & 0.8810 & 2.96 & & 0.0105 \\
\hline
\end{tabular}


TABLE 5 (Continued)

\begin{tabular}{|c|c|c|c|c|c|c|c|c|c|}
\hline \multirow[b]{2}{*}{$\begin{array}{c}\text { Census Bureau } \\
\text { Divisions }\end{array}$} & \multicolumn{3}{|c|}{ Environmental Protection } & \multicolumn{3}{|c|}{ Employment Training } & \multicolumn{3}{|c|}{ Highways } \\
\hline & Estimate & $\begin{array}{c}\text { T- } \\
\text { Statistic }\end{array}$ & $\begin{array}{c}\text { Signif- } \\
\text { icance } \\
\text { Level }\end{array}$ & Estimate & $\begin{array}{c}\text { T- } \\
\text { Statistic }\end{array}$ & $\begin{array}{c}\text { Signif- } \\
\text { icance } \\
\text { Level }\end{array}$ & Estimate & $\begin{array}{c}\text { T- } \\
\text { Statistic }\end{array}$ & $\begin{array}{c}\text { Signif- } \\
\text { icance } \\
\text { Level }\end{array}$ \\
\hline Intercept & 0.0148 & 4.66 & 0.0001 & 0.0238 & 23.64 & 0.0001 & 0.0429 & 4.95 & 0.0001 \\
\hline New England & 0.0137 & 2.82 & 0.0074 & 0.0019 & 1.27 & 0.2105 & -0.0104 & -0.79 & 0.4348 \\
\hline Mid Atlantic & 0.0073 & 1.20 & 0.2353 & 0.0031 & 1.63 & 0.1106 & -0.0245 & -1.48 & 0.1464 \\
\hline East North Central & 0.0090 & 1.75 & 0.0869 & -0.0013 & -0.84 & 0.4049 & -0.0190 & -1.36 & 0.1811 \\
\hline West North Central & -0.0022 & -1.48 & 0.6355 & -0.0055 & -3.75 & 0.0006 & 0.0019 & 0.15 & 0.8794 \\
\hline Mountain & -0.0002 & -0.07 & 0.9473 & -0.0027 & -1.91 & 0.0636 & 0.0247 & 2.02 & 0.0502 \\
\hline Pacific & 0.0054 & 1.07 & 0.2910 & 0.0007 & 0.46 & 0.6471 & 0.0284 & 2.04 & 0.0480 \\
\hline East South Central & -0.0047 & -0.86 & 0.3926 & 0.0016 & 0.95 & 0.3488 & -0.0026 & -0.17 & 0.8629 \\
\hline West South Central & -0.0049 & -0.89 & 0.3784 & -0.0022 & -1.26 & 0.2138 & -0.0147 & -0.98 & 0.3316 \\
\hline Mean & 0.0172 & & & 0.0229 & & & 0.0440 & & \\
\hline $\mathrm{R}^{2}$ & 0.3487 & & & 0.4966 & & & 0.3637 & & \\
\hline F value & 2.74 & & 0.0160 & 5.06 & & 0.0002 & 2.93 & & 0.0110 \\
\hline
\end{tabular}


TABLE 6

Federal Aid Per Capita by Categories, Adjusted, 1979

\begin{tabular}{|c|c|c|c|c|c|c|c|c|c|}
\hline \multirow[b]{2}{*}{$\begin{array}{l}\text { Census Bureaus } \\
\text { Divisions }\end{array}$} & \multicolumn{3}{|c|}{ Health and Welfare } & \multicolumn{3}{|c|}{ Education } & \multicolumn{3}{|c|}{$\begin{array}{c}\text { Housing and Community } \\
\text { Development }\end{array}$} \\
\hline & Estimate & $\begin{array}{c}\mathrm{T}- \\
\text { Statistic }\end{array}$ & $\begin{array}{l}\text { Signif- } \\
\text { icance } \\
\text { Level }\end{array}$ & Estimate & $\begin{array}{c}\mathrm{T}- \\
\text { Statistic }\end{array}$ & $\begin{array}{l}\text { Signifi- } \\
\text { icance } \\
\text { Level }\end{array}$ & Estimate & $\begin{array}{c}\text { T- } \\
\text { Statistic }\end{array}$ & $\begin{array}{l}\text { Signifi- } \\
\text { icance } \\
\text { Level }\end{array}$ \\
\hline Intercept & 0.2690 & 4.44 & 0.0001 & 0.0286 & 3.12 & 0.0036 & 0.0249 & 2.93 & 0.0058 \\
\hline New England & 0.0788 & 3.86 & 0.0004 & -0.0043 & -1.41 & 0.1680 & 0.0073 & 2.56 & 0.0147 \\
\hline Mid Atlantic & 0.0833 & 3.24 & 0.0026 & -0.0065 & -1.67 & 0.1032 & 0.0052 & 1.44 & 0.1573 \\
\hline East North Central & 0.0502 & 2.40 & 0.0217 & -0.0032 & -1.02 & 0.3138 & -0.0024 & -0.84 & 0.4075 \\
\hline West North Central & 0.0099 & 0.52 & 0.6092 & -0.0028 & -0.97 & 0.3385 & 0.0021 & 0.78 & 0.4382 \\
\hline Mountain & -0.0210 & -1.14 & 0.2636 & -0.0018 & -0.67 & 0.5060 & -0.0056 & -2.17 & 0.0367 \\
\hline Pacific & 0.0356 & 1.50 & 0.1431 & -0.0051 & -1.42 & 0.1639 & -0.0057 & -1.72 & 0.0935 \\
\hline East South Central & 0.0130 & 0.57 & 0.5740 & -0.0004 & -0.13 & 0.8979 & 0.0031 & 0.98 & 0.3332 \\
\hline West South Central & 0.0393 & 1.81 & 0.0792 & -0.0004 & -0.13 & 0.8946 & 0.0016 & 0.53 & 0.6002 \\
\hline $\begin{array}{l}\text { State and Local } \\
\text { Taxes Per Capita }\end{array}$ & 0.0733 & 2.51 & 0.0165 & 0.0189 & 4.28 & 0.0001 & 0.0165 & 4.04 & 0.0003 \\
\hline $\begin{array}{l}\text { State Income Per } \\
\text { Capita }\end{array}$ & -0.0302 & -2.93 & 0.0059 & -0.0027 & -1.75 & 0.0890 & -0.0027 & -1.91 & 0.0644 \\
\hline $\begin{array}{l}\text { Percentage of } \\
\text { Population in } \\
\text { Urban Area }\end{array}$ & 0.0005 & 1.41 & 0.1678 & -7.1588 & -1.29 & 0.2046 & 0.0001 & 2.57 & 0.0145 \\
\hline Mean & 0.1383 & & & 0.0159 & & & 0.0250 & & \\
\hline $\mathrm{R}^{2}$ & 0.5800 & & & 0.4874 & & & 0.6156 & & \\
\hline $\mathrm{F}$ value & 4.52 & & 0.0003 & 3.11 & & 0.0049 & 5.24 & & 0.0001 \\
\hline
\end{tabular}


TABLE 6 (Continued)

\begin{tabular}{|c|c|c|c|c|c|c|c|c|c|}
\hline \multirow[b]{2}{*}{$\begin{array}{c}\text { Census Bureau } \\
\text { Divisions }\end{array}$} & \multicolumn{3}{|c|}{ Environmental Protection } & \multicolumn{3}{|c|}{ Employment Training } & \multicolumn{3}{|c|}{ Highways } \\
\hline & Estimate & $\begin{array}{c}\text { T- } \\
\text { Statistic }\end{array}$ & $\begin{array}{l}\text { Signif- } \\
\text { icance } \\
\text { Level }\end{array}$ & Estimate & $\begin{array}{c}\mathrm{T}- \\
\text { Statistic }\end{array}$ & $\begin{array}{l}\text { Signif- } \\
\text { icance } \\
\text { Level }\end{array}$ & Estimate & $\begin{array}{c}\mathrm{T}- \\
\text { Statistic }\end{array}$ & $\begin{array}{l}\text { Signif- } \\
\text { icance } \\
\text { Level }\end{array}$ \\
\hline Intercept & -0.0311 & -2.29 & 0.0279 & 0.0259 & 5.64 & 0.0001 & 0.0222 & 0.95 & 0.3486 \\
\hline New England & 0.0112 & 2.46 & 0.0188 & 0.0020 & 1.33 & 0.1919 & -0.0185 & -2.35 & 0.0241 \\
\hline Mid Atlantic & 0.0080 & 1.40 & 0.1701 & 0.0026 & 1.35 & 0.1840 & -0.0304 & -3.06 & 0.0041 \\
\hline East North Central & 0.0055 & 1.18 & 0.2459 & -0.0013 & -0.83 & 0.4101 & -0.0173 & -2.14 & 0.0388 \\
\hline West North Central & -0.0048 & -1.12 & 0.2705 & -0.0051 & -3.53 & 0.0012 & -0.0095 & -1.28 & 0.2072 \\
\hline Mountain & 0.0007 & 0.19 & 0.8531 & -0.0016 & -1.15 & 0.2597 & 0.0110 & 1.54 & 0.1320 \\
\hline Pacific & 0.0024 & 0.46 & 0.6451 & 0.0005 & 0.32 & 0.7476 & -0.0037 & -0.41 & 0.6830 \\
\hline East South Central & 0.0007 & 0.14 & 0.8911 & 0.0014 & 0.85 & 0.4023 & 0.0012 & 0.14 & 0.8862 \\
\hline West South Central & -0.0050 & -1.04 & 0.3038 & -0.0021 & -1.28 & 0.2098 & -0.0090 & -1.07 & 0.2909 \\
\hline $\begin{array}{l}\text { State and Local } \\
\text { Taxes Per Capita }\end{array}$ & -0.0180 & -2.77 & 0.0089 & 0.0018 & 0.83 & 0.4138 & 0.0716 & 6.35 & 0.0001 \\
\hline $\begin{array}{l}\text { State Income Per } \\
\text { Capita }\end{array}$ & 0.0086 & 3.72 & 0.0007 & -0.0006 & -0.78 & 0.4388 & -0.0002 & -0.07 & 0.9441 \\
\hline $\begin{array}{l}\text { Percentage of } \\
\text { Population in } \\
\text { Urban Area }\end{array}$ & -0.0001 & -1.85 & 0.0731 & 2.2044 & 0.79 & 0.4328 & -0.0005 & -4.15 & 0.0002 \\
\hline Mean & 0.0171 & & & 0.0230 & & & 0.0429 & & \\
\hline $\mathrm{R}^{2}$ & 0.5127 & & & 0.5412 & & & 0.8128 & & \\
\hline $\mathrm{F}$ value & 3.44 & & 0.0024 & 3.86 & & 0.0010 & 14.21 & & 0.0001 \\
\hline
\end{tabular}


share-as was intended-in the growth of fiscal federalism. The lack of significance attached to the change in the urbanization variable suggests that the disadvantage experienced by urban areas in 1970 was not in any statistically reliable way altered by 1979 .

\section{DISAGGREGATED FEDERAL AID FLOWS TO STATES}

\section{The Unadjusted Flows}

Aggregate data on federal aid flows can hide variations in the distribution of funds under various program categories. A positive regional bias inherent in highway programs can offset a negative regional bias in social service programs. Federal aid under six major programs in existence in 1979-health and welfare, education, housing, environmental protection, employment training, and highways - was analyzed on a per capita basis for regional biases. The results, unadjusted for state income, state and local taxes, and extent of urbanization, are shown in Table 5. Using a .10 significant level as a benchmark, the following observations can be drawn. Relative to the South Atlantic,

- The New England, Mid Atlantic, and East North Central enjoyed an regional advantage in securing federal aid for health and welfare services on a per capita basis;

- No division experienced an advantage in the distribution of federal aid for education;

- The New England and Mid Atlantic divisions benefited disproportionately in housing aid, whereas the Mountain division was disadvantaged in housing aid;

- The New England and East North Central divisions received a significantly greater amount of aid for environmental protection than other divisions;

- The West North Central and Mountain divisions were disadvantaged in terms of the amount of employment assistance aid received from the federal government; however,

- The Mountain states enjoyed an advantage in the amount of highway aid received.

Aside from federal aid to education, the equations are reasonably strong in their explanatory power, even without adjusting for important economic forces.

\section{The Adjusted Flows}

Along with the dummy variables for the Census Bureau divisions, state and local taxes per capita, state income per capita, and the extent of urbanization were regressed, in independent runs for 1979, against the above six categories of federal aid per capita. Because the way in which federal aid was categorized and changed during the decade, a comparison between 1970 and 1979 findings was not attempted. Only the results for 
TABLE 7

Federal Aid Per Capita to Northeast-Midwest and Rest of Country, Adjusted, 1970 and 1979

\begin{tabular}{|c|c|c|c|c|c|c|}
\hline \multirow[b]{2}{*}{$\begin{array}{c}\text { Census Bureau } \\
\text { Divisions }\end{array}$} & \multicolumn{3}{|c|}{1970} & \multicolumn{3}{|c|}{1979} \\
\hline & Estimate & T-Statistic & $\begin{array}{c}\text { Significance } \\
\text { Level }\end{array}$ & Estimate & T-Statistic & $\begin{array}{c}\text { Significance } \\
\text { Level }\end{array}$ \\
\hline Intercept & 0.1159 & 5.61 & 0.0001 & 0.4946 & 7.86 & 0.0001 \\
\hline Northeast-Midwest* & -0.0363 & -3.57 & 0.0009 & -0.0088 & -0.62 & 0.5410 \\
\hline $\begin{array}{l}\text { State Income Per } \\
\text { Capita }\end{array}$ & 0.0014 & 0.12 & 0.9077 & -0.0513 & -4.54 & 0.0001 \\
\hline $\begin{array}{l}\text { State and Local } \\
\text { Taxes Per Capita }\end{array}$ & 0.1476 & 1.60 & 0.1170 & 0.4249 & 12.91 & 0.0001 \\
\hline $\begin{array}{l}\text { Percentage of } \\
\text { Population in } \\
\text { Urban Areas }\end{array}$ & -0.0007 & -4.00 & 0.0002 & -0.0010 & -2.52 & 0.0157 \\
\hline Mean & 0.1270 & & & 0.3862 & & \\
\hline $\mathrm{R}^{2}$ & 0.4838 & & & 0.8453 & & \\
\hline $\mathrm{F}$ value & 10.55 & & 0.0001 & 58.75 & & 0.0001 \\
\hline
\end{tabular}

* The Northeast-Midwest includes those states that are a part of the Northeast-Midwest Congressional Coalition: Connecticut, Delaware, Illinois, Indiana, Iowa, Maine, Maryland, Massachusetts, Michigan, Minnesota, New Hampshire, New Jersey, New York, Ohio, Pennsylvania, Rhode Island, Vermont, and Wisconsin. Those states in the Northeast-Midwest were given a 1 ; those outside the area, 0 . 
TABLE 8

Federal Aid to the Northeast-Midwest and Rest of the Country, by Categories and Adjusted, 1979

\begin{tabular}{|c|c|c|c|c|c|c|c|c|c|}
\hline \multirow[b]{2}{*}{$\begin{array}{l}\text { Census Bureau } \\
\text { Divisions }\end{array}$} & \multicolumn{3}{|c|}{ Health and Welfare } & \multicolumn{3}{|c|}{ Education } & \multicolumn{3}{|c|}{$\begin{array}{l}\text { Housing and Community } \\
\text { Development }\end{array}$} \\
\hline & Estimate & $\begin{array}{c}\mathrm{T}- \\
\text { Statistic }\end{array}$ & $\begin{array}{l}\text { Signif- } \\
\text { icance } \\
\text { Level }\end{array}$ & Estimate & $\begin{array}{c}\mathrm{T}- \\
\text { Statistic }\end{array}$ & $\begin{array}{l}\text { Signif- } \\
\text { icance } \\
\text { Level }\end{array}$ & Estimate & $\begin{array}{c}\mathrm{T}- \\
\text { Statistic }\end{array}$ & $\begin{array}{l}\text { Signif- } \\
\text { icance } \\
\text { Level }\end{array}$ \\
\hline Intercept & 0.2868 & 5.12 & 0.0001 & 0.0308 & 4.20 & 0.0001 & 0.0367 & 4.37 & 0.0001 \\
\hline Northeast-Midwest & 0.0511 & 4.02 & 0.0002 & -0.0022 & -1.35 & 0.1837 & 0.0048 & 2.54 & 0.0147 \\
\hline $\begin{array}{l}\text { State Income Per } \\
\text { Capita }\end{array}$ & -0.0346 & -3.44 & 0.0013 & -0.0030 & -2.29 & 0.0272 & -0.0043 & -2.86 & 0.0066 \\
\hline $\begin{array}{l}\text { State and Local } \\
\text { Taxes Per Capita }\end{array}$ & 0.0887 & 3.03 & 0.0041 & 0.0168 & 4.38 & 0.0001 & 0.0155 & 3.55 & 0.0010 \\
\hline $\begin{array}{l}\text { Percentage of } \\
\text { Population in } \\
\text { Urban Areas }\end{array}$ & 0.0007 & 2.01 & 0.0511 & -6.5652 & -1.40 & 0.1682 & 0.0001 & 2.64 & 0.0116 \\
\hline Mean & 0.1383 & & & 0.0160 & & & 0.0250 & & \\
\hline $\mathrm{R}^{2}$ & 0.3934 & & & 0.4449 & & & 0.3694 & & \\
\hline F value & 6.97 & & 0.0002 & 8.62 & & 0.0001 & 6.30 & & 0.0004 \\
\hline
\end{tabular}


TABLE 8

Federal Aid to the Northeast-Midwest and Rest of the Country, by Categories and Adjusted, 1979

\begin{tabular}{|c|c|c|c|c|c|c|c|c|c|}
\hline \multirow[b]{2}{*}{$\begin{array}{l}\text { Census Bureau } \\
\text { Divisions }\end{array}$} & \multicolumn{3}{|c|}{$\begin{array}{l}\text { Environmental } \\
\text { Protection }\end{array}$} & \multicolumn{3}{|c|}{$\begin{array}{l}\text { Employment } \\
\text { Training }\end{array}$} & \multicolumn{3}{|c|}{ Highways } \\
\hline & Estimate & $\begin{array}{c}\mathrm{T}- \\
\text { Statistic }\end{array}$ & $\begin{array}{l}\text { Signif- } \\
\text { icance } \\
\text { Level }\end{array}$ & Estimate & $\begin{array}{c}\text { T- } \\
\text { Statistic }\end{array}$ & $\begin{array}{l}\text { Signif- } \\
\text { icance } \\
\text { Level }\end{array}$ & Estimate & $\begin{array}{c}\text { T- } \\
\text { Statistic }\end{array}$ & $\begin{array}{l}\text { Signif- } \\
\text { icance } \\
\text { Level }\end{array}$ \\
\hline Intercept & -0.0295 & -2.47 & 0.0175 & 0.0290 & 6.14 & 0.0001 & 0.0184 & 0.94 & 0.3545 \\
\hline Northeast-Midwest & 0.0055 & 2.06 & 0.0456 & 0.0008 & 0.82 & 0.4192 & -0.0208 & -4.65 & 0.0001 \\
\hline $\begin{array}{l}\text { State Income Per } \\
\text { Capita }\end{array}$ & 0.0074 & 3.48 & 0.0012 & -0.0018 & -2.17 & 0.0352 & 0.0003 & 0.11 & 0.9115 \\
\hline $\begin{array}{l}\text { State and Local } \\
\text { Taxes Per Capita }\end{array}$ & -0.0136 & -2.19 & 0.0340 & 0.0051 & 2.06 & 0.0450 & 0.0711 & 6.91 & 0.0001 \\
\hline $\begin{array}{l}\text { Percentage of } \\
\text { Population in } \\
\text { Urban Areas }\end{array}$ & -9.3258 & -1.22 & 0.2273 & 7.5183 & 2.49 & 0.0166 & -0.0005 & -4.76 & 0.0001 \\
\hline Mean & 0.0171 & & & 0.0231 & & & 0.0429 & & \\
\hline $\mathrm{R}^{2}$ & 0.3632 & & & 0.1810 & & & 0.7771 & & \\
\hline $\mathrm{F}$ value & 6.13 & & 0.0005 & 2.38 & & 0.0669 & 37.49 & & 0.0001 \\
\hline
\end{tabular}


1979 are reported in Table 6. Relative to the South Atlantic division, the following conclusions can be drawn:

- The New England, Mid Atlantic, East North Central, and West South Central received health and welfare benefits disproportionate to their population, income, taxes, and degree of urbanization;

- Although all of the regional variables have negative signs, as in the unadjusted runs, there was no statistically significant regional bias in the distribution of education benefits;

- Federal aid for housing favored the New England states and worked to the disadvantage of the Mountain and Pacific states;

- Only New England received more than its proportionate share of environmental protection funds (the adjustments eliminated the regional bias found above for the East North Central);

- West North Central took in less than its proportionate amount of employment training aid (the disadvantage of the Mountain states was eliminated by the adjustments); and

- New England, Mid Atlantic, and East North Central states experienced a disadvantage in the distribution of highway funds.

Overall, the negative influence of urbanization on the distribution of aggregate federal aid per capita, discussed in an earlier section, appears to have been due to the way in which federal highway and environmental protection funds were distributed. Given the absence of high ways in metropolitan areas, those findings are not unexpected. The distribution of environmental protection funds to cities is, however, surprising.

State income had a negative effect in three of the aid categories: health and welfare benefits, education, and housing, a finding in line, apparently, with the presumed redistributive objectives of the programs. On the other hand, federal environmental protection funds were positively affected by state income, suggesting that environmental protection redistributes purchasing power from low to high income states.

Except for two categories, environmental protection and employment training, state and local taxes had a significant positive effect on the distributional flows of federal aid. In the case of environmental protection, the sign on state and local taxes is negative and significant. In the case of employment training assistance, a statistical relationship cannot be established.

\section{THE NORTHEAST-MIDWEST VERSUS THE REST OF THE COUNTRY}

\section{Aggregate Federal Aid Flows}

Note was made at the beginning that the Northeast-Midwest Congressional Coalition feels strongly that it is failing to get its "fair share" of federal aid. To address that issue directly, additional regression equations were run, using a dummy variable (with 1 for the states in the NortheastMidwest coalition ${ }^{8}$ and 0 for all other states). The results for the aggregate 
flow of federal aid are reported in Table 7. It retells a story that is reported in fragmented form above: after adjusting for per capita income and state and local taxes and degree of urbanization and in terms of aggregate aid flows, there was a strong bias against the Northeast-Midwest in 1970, but not in $1979 .{ }^{9}$ That general conclusion is left unaffected by the elimination of the urbanization variable.

\section{Disaggregated Federal Aid Flows}

Table 8 reports the last step in our analysis, the flow of aid by categories to the Northeast-Midwest in 1979. That analysis reconfirms our results reported above, namely that the Northeast-Midwest area as a whole was favored by federal health and welfare, housing and community development, and environmental programs. Those advantages were obscured in the aggregate data by the negative effects of federal education programs (nonsignificant) and highway programs (significant).

\section{CONCLUDING COMMENTS}

Given all of the media discussion concerning the "Sunbelt-Frostbelt Confrontation" surrounding federal aid flows, the biases (or absence thereof) in the regional distribution of aggregate federal aid is somewhat surprising. Distributional biases do exist in favor of the Frostbelt, especially when unadjusted aggregate aid levels are considered. However, many of those biases understandably disappear when the aid flows are adjusted first for population differences and then for measures of state and local fiscal capacity. The analysis presented here indicates that the South Atlantic may be as disadvantaged with regard to the total federal aid it receives as the Mid Atlantic.

Generally, the results indicate a strong bias against the NortheastMidwest in 1970, which evaporated during the decade. Perhaps, northerners' concern over the distribution of the federal aid stems from the fact that during the 1970s they saw their advantage from the federal aid system wiped out by the realignment of political power. The trend is threatening; they have progressively received less in return for the federal taxes they have paid (because of their generally higher income levels and the progressive federal tax system).

Will a cutback in federal aid to states disadvantage any particular region of the country? The answer to that question is not totally clear. The Northeast may lose part of the advantage it has garnered through health and welfare, environmental protection, and housing and community development programs. However, that area of the country, which generally has higher than average incomes, will not have to endure the negative consequences of federal aid programs that tend to redistribute income from high to low income states. If the aid cuts are across the board and are accompanied by cuts in federal tax rates, from this study it appears that the 
Northeast-Midwest will gain on balance: it will not be discriminated against in terms of federal aid flows (given our 1979 findings), but it will gain by way of disproportional reductions in federal taxes paid.

\section{FOOTNOTES}

'Lillian Rymarowicz, "Tablulations: Estimated Federal Tax Payments by Residents of Individual States Compared to Estimated Outlays in the States, Fiscal Year 1979" (Washington: Congressional Research Service, July 9, 1980), pp. 1-2 and 5-6.

2The Northeast-Midwest area includes the states of Connecticut, Delaware, Illinois, Indiana, Iowa, Maine, Maryland, Massachusetts, Michigan, Minnesota, New Hampshire, New Jersey, New York, Ohio, Pennsylvania, Rhode Island, Vermont, and Wisconsin.

${ }^{3}$ Jacqueline Mazza and Bill Hogan, eds., The State of the Region in 1981: Ecomomic Trends in the Northeast and Midwest (Washington: Northeast-Midwest Institute and Northeast-Midwest Congressional Coalition, 1981), p.37.

${ }^{4}$ Ibid., p. 43

${ }^{5}$ The selection of the Census Bureau division that would not be included in the regression equations was more or less arbitrary. The South Atlantic was chosen simply because of the author's personal interest in the region.

${ }^{6}$ Categorical Grants: Their Role and Design (Washington: Advisory Commission on Intergovernmental Relations, 1978). See also Berrier E. Frye and Richard B. McKenzie, "Impact of Federal Aid on State and Local Taxes" (Clemson, S.C.: Economics Department, Clemson University, 1982).

${ }^{7}$ Richard B. McKenzie and Bruce Yandle, "The Distribution of Federal Aid to States: The Impact of Delegation Size" (Clemson S.C.: Economics Department, Clemson University, 1982).

${ }^{8}$ See footnote 2 for the states included in the Northeast-Midwest.

${ }^{9}$ The correlation coefficient between personal income and the Northeast-Midwest dummy variable is .288 for 1970 and .277 for 1979, which indicates an absence of a problem of multicolinearity. 